\title{
TOPICS IN TAITA TONE II $^{\star}$
}

\author{
David Odden \\ Ohio State University
}

\begin{abstract}
This paper describes aspects of tone in the Mbololo dialect of Taita, compariing it to the Dembwa dialect described in Odden (2001). A salient feature of tone in the language is a covert lexical distinction between words with final $\mathrm{H}$ versus those with no final tone. Phrasal tone alternations provide ample evidence allowing the recovery of this underlying distinction. The language also has a process of rightward $\mathrm{H}$ tone shift, also found in languages such as Jita and Dembwa Taita. In contrast to Dembwa Taita, where language-internal evidence clearly indicates that surface shift is the result of general spreading and restricted delinking, the patterns of spread and delinking in Mbololo Taita are perfectly matched, so that there is no synchronic evidence for a two-step account of tone shift.
\end{abstract}

\section{Introduction.}

The Bantu language Mbololo is one of the dialects of Davida (E74a), a sister language of Saghala (E74b) within the Taita subgroup of Bantu, which is spoken in southeastern Kenya. The purpose of this paper is to continue the description of tone in the language started in Odden (2001), which describes aspects of tone in the Dembwa dialect, and to provide comparative background on how the system may have developed. Philippson (1991) and Philippson \& Montlahuc (2003) provide Davida data, from the Josa dialect, which is briefly discussed in the last section, along with some data from the Rong'e dialect.

* Data for this paper was collected in Nairobi during April-May 1997 with the assistance of Renson Mbogho, as well as Rose Lugano for the data from Rong'e, and was supported financially by NSF Grant SBR-9421362 and, in part, CASTL, University of Tromsø. Earlier versions of this paper were presented at ACAL 36 in Savannah and CALL 35 in Leiden. I would like to thank Robert Botne and two anonymous reviewers for helpful comments on this paper. 
Like the more distantly related Bantu languages Rimi, Kikuyu, Sukuma and Jita, and the more closely related Chaga and the mutually intelligible dialect Dembwa Taita (henceforth "Dembwa"), Mbololo Taita (henceforth "Mbololo") has rightward shift of $\mathrm{H}$ tones from their underlying position. Tone shift is a typological anomaly - one does not find "voicing shift" or "rounding shift" in languages, and stress shift, perhaps the closest analogue to tone shift, is heavily conditioned by rhythmic factors that play little role in tone shift - and therefore investigation into the nature of tone shift potentially reveals something unique about the nature of the human language faculty. The quality of any such crosslinguistic investigation depends on the availability of the fullest range possible of basic descriptions of the facts. This paper seeks to contribute to our knowledge of phonology by expanding the database of language description to include a previously undescribed tonal system.

Section 2 of the paper discusses NP-internal alternations of tone, focusing on evidence for the distinction between surface toneless nouns which have an underlying word-final $\mathrm{H}$, versus those stems with no underlying $\mathrm{H}$ tone, a distinction which is neutralized in citation forms in favor of a toneless pattern. This section also presents evidence for phrasal rules which insert and dock a $\mathrm{H}$ tone between a noun and a modifier, rules which partially obscure the underlying final $\mathrm{H}$ vs. toneless distinction. These rules interact with Meeussen's Rule, which deletes a $\mathrm{H}$ tone after a $\mathrm{H}$ - in Mbololo, this affects only floating tones. A further problem is posed by the existence of modifiers which do not trigger phrasal $\mathrm{H}$ tone insertion. It is shown that the number of underlying syllables in the modifier affects whether phrasal $\mathrm{H}$ is inserted, so that underlyingly disyllabic modifiers do not cause H-insertion. Finally, subject noun plus verb constructions are considered, further supporting the proposed underlying tonal distinctions in nouns and showing that phrasal $\mathrm{H}$-insertion is limited to applying within the NP.

Section 3 considers tone in verbs, including interaction between verb and following noun, which provides evidence for a reflex of the common Bantu system of melodic tone inflection as part of the tense-aspect system. The final section compares the system of tonal alternations of Dembwa and Mbololo, and considers the historical development of lexical distinctions in nouns.

\section{Noun Tone.}

Since nominal word-formation processes in Taita contribute negligibly to tonal alternations, there is little to say about word-internal noun tone. However, phrasal combinations of noun plus word, or word plus noun, do give rise to interesting 
alternations whose nature is not immediately obvious. An investigation of lexically-governed alternations between citation and modified forms in 2.1 motivates an opaque distinction between nouns with final $\mathrm{H}$ versus those with no $\mathrm{H}$, considering combinations of noun plus adjective and noun plus certain numerals in 2.1. Failure of phrasal $\mathrm{H}$ insertion before "tonally inert" modifiers is discussed in 2.2. Section 2.3 considers the tone of nouns in preverbal position.

2.1 Noun + adjective constructions. There are two main surface tone classes of nouns in Mbololo: those with a $\mathrm{H}$ on the penultimate syllable, and those which are surface toneless. Examples of penult-H nouns are given in (1).
(1)
ifúmu
'spear'
lúmbo
'song'
msénge
'walking stick'
msídu
'forest'
mukábo
'vertical stud'
ngánga
'guinea fowl'
yóndi
'sheep'

Surface toneless nouns are given in (2), with the data being divided into two morphophonemic classes, which will be justified below.

\begin{tabular}{|c|c|c|c|}
\hline a. i $і$ e $\gamma о$ & 'tooth' & iүembe & 'hoe' \\
\hline masoka & 'axe' & kijiko & 'spoon' \\
\hline kikoto & 'hand' & lundi & 'rafter' \\
\hline lwau & 'foot' & mudi & 'tree' \\
\hline$\beta$ andu & 'people' & mungulu & 'bean' \\
\hline miri & 'roots' & muzi & 'village' \\
\hline mayu & ‘legs' & Balimi & 'farmers' \\
\hline
\end{tabular}

1 Transcriptions of data given are in phonetic transcription where $j$ represents a voiced alveopalatal affricate (IPA [d 3$]$ ), $\check{s}$ is a voiceless alveopalatal fricative (IPA [J]) and $\check{c}$ is a voiceless alveopalatal fricative (IPA [tf]). In addition, $n g$ is phonetically [ng]. This differs from the quasi-orthography for consonants used in Odden (2001). Unlike Dembwa, which allows both level $\mathrm{H}$ and falling tone on the penult, in Mbololo, the phrasal penult is somewhat lengthened, but the length of the penult has no phonological consequences, a $\mathrm{H}$ toned penult always having level $\mathrm{H}$ pitch. Some nouns in classes 1 and 3, which have the noun class prefix /mu/, realize that prefix in these examples as [m], e.g. [msénge] 'walking stick', while others realise the prefix as [mu], e.g. [muká6o] 'vertical stud'. I have not investigated the circumstances surrounding this alternation thoroughly but it appears that $/ \mathrm{mu} /$ reduces to [m] optionally. Examples are presented here in the form in which I record them in my notes. Any dishomorganic $[\mathrm{mC}]$ cluster has syllabic $\left[\mathrm{m}_{1}\right]$, so syllabicity is marked only before a labial. 


\begin{tabular}{|c|c|c|c|}
\hline b. Bukuta & 'wall' & iriso & 'eye' \\
\hline ituku & 'day' & kiju & 'shadow' \\
\hline lumi & 'tongue' & mikonu & 'arms' \\
\hline mori & 'moon' & mukame & 'sp. tree' \\
\hline Bana & 'child' & & \\
\hline
\end{tabular}

Nouns with an overt $\mathrm{H}$ tone such as in (1) are significantly less common, compared to surface toneless nouns such as in (2).

While there is no reason to distinguish the two subsets of nouns (2a) and (2b) given just the citation forms of the nouns, phrasal phonology provides evidence for an underlying distinction. As seen in (3) and (4), the citation-toneless class must be differentiated into two sub-classes before an adjective. In the group (2a), to be referred to as the "toneless nouns", the first syllable of the following adjective, which is usually a noun class agreement prefix, has $\mathrm{H}^{2}$

\begin{tabular}{|c|c|c|c|}
\hline iүeyo 1-6aha & 'big tooth' & i $\gamma$ embe $1-6 a h a$ & 'big hoe' \\
\hline masoka má-lača & 'long axes' & kijiko ḱ1-lača & 'long spoon' \\
\hline kikoto ḱ1-6aha & 'big hand' & lundi lú-lača & 'long rafter' \\
\hline lwau lú-lača & 'long foot' & mudi mú-lača & 'tall tree' \\
\hline 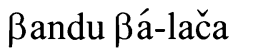 & 'tall people' & mingulu mí-6aha & 'big beans' \\
\hline muzi mé-6aha & 'big village' & miri $1-$ dadu & '3 roots' \\
\hline mayu á-dadu & '3 legs' & $\beta$ alimi $\beta a ́$-linga & $\mathrm{V}$ many \\
\hline 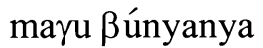 & '8 legs' & & farmers?' \\
\hline
\end{tabular}

Since such nouns are themselves toneless in phrase-medial context, it is reasonable to assume that these nouns are underlyingly toneless.

In the other group, (2b) — the "H nouns" - a final H emerges on the last vowel of the noun.

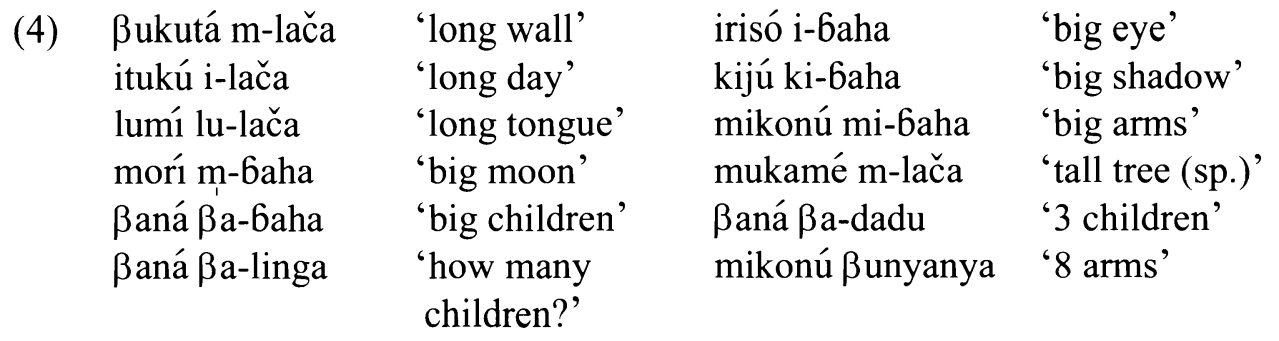

${ }^{2}$ However, the numeral 'eight', among others, does not agree in class with the head noun. 
These data present two puzzles: what lexical property distinguishes the nouns of (4) which have a final $\mathrm{H}$ before an adjective from those of (3) which do not, and what explains the presence of $\mathrm{H}$ on the adjective in (3) and its lack in (4)?

The tone alternation in the adjective could be explained by positing a $\mathrm{H}$ tone on the adjective prefix which is directly manifested in (3) and is deleted after a final $\mathrm{H}$ in (4) - hypothesizing /itukú ílača/ $\rightarrow$ [itukú ilača]. Alternatively, the data can be explained by assuming that the adjective prefix is underlyingly toneless, so that (4) involves no rule application, and we can explain the data of (3) by insertion of $\mathrm{H}$ on the adjective when no $\mathrm{H}$ is present in the preceding word, thus

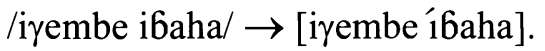

There is additional evidence to support the latter insertion approach. The adjective is also toneless when it comes after a penult-H noun: such nouns do not themselves undergo tonal alternations.

$\begin{array}{llll}\text { ifúmu i-6aha } & \text { 'big spear' } & \text { lúmbo lu-lača } & \text { 'long song' } \\ \text { misénge mi-lača } & \text { 'long stick } & \text { mśídu m-6aha } & \text { 'big forest' } \\ \text { miká6o mi-lača } & \text { 'long stud' } & \text { yóndi m-baha } & \text { 'big sheep' } \\ \text { ngánga m-baha } & \text { 'big guinea fowl' } & \text { sa6úni n-dača } & \text { 'long soap' }\end{array}$

This fact follows directly from the assumption that the adjective is toneless, and receives $\mathrm{H}$ only after a toneless noun. In addition, we also find that the adjective is toneless in its citation form.
(6) lulača
'long (cl. 11)' milača
'long (cl. 4)'
mbaha
'big (cl. 3)'
kibaha
'big (cl. 7)'

Since the nouns of (3) do not have a surface $\mathrm{H}$ tone either in citation forms or phrasally, in the data considered so far, the most transparent account of them, the one adopted here, posits that the toneless nouns are underlyingly toneless. They thus differ from the $\mathrm{H}$ nouns, which have an underlying $\mathrm{H}$ tone. Since that $\mathrm{H}$ is not always manifested on the surface, the question arises as to where that $\mathrm{H}$ is associated underlyingly, if it is associated at all. Four imaginable accounts of the H noun iriso 'eye' are given in (7).
(7)

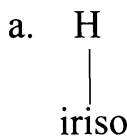
b. $\bigwedge_{\text {iriso }}^{\mathrm{H}}$
c. $\underset{\text { iriso }}{\mathrm{H}}$
d. $\mathrm{H}$
iriso 
We can rule out representation (7a) for two reasons. First, that would falsely render $\mathrm{H}$ nouns indistinguishable from non-alternating penult- $\mathrm{H}$ nouns such as [miká6o]. Second, there are monosyllabic roots in the set of $\mathrm{H}$ nouns, e.g. [ki-ju] 'shadow', [vi-ju] 'shadows', [ßu-šu] 'face' — see kijú kibaha 'big shadow', $\beta$ šśu mlača 'long face'. An underlying representation which requires the $\mathrm{H}$ nouns to lexically bear tone on the penultimate syllable predicts that there would be no monosyllabic roots in the $\mathrm{H}$ class, and yet there are. This reduces the choices of underlying form to $(7 \mathrm{c})$ or $(7 \mathrm{~d})$, either with a floating $\mathrm{H}$ or a $\mathrm{H}$ linked to the last syllable.

Providing a more explicit account of the adjectival tone alternation helps to narrow the choice of underlying form for nouns down to (7c). I assume underlying /irisó/, which undergoes the Prepausal H Deletion rule (8) — “\#\#" indicates prepausal position in that rule.

\section{Prepausal H Deletion}

$\mathrm{H} \rightarrow \varnothing / \ldots \#$

Since the adjectival $\mathrm{H}$ is not underlyingly present, it must be inserted and associated. As seen below, the surface realization of the adjectival $\mathrm{H}$ can vary according to phonological properties of the phrase. I assume the Phrasal H Insertion rule (9).

$$
\begin{aligned}
& \text { Phrasal H Insertion } \\
& \varnothing \rightarrow \mathrm{H} /\left[\mathrm{NP}\left[\mathrm{N} \_\right][\ldots]\right]
\end{aligned}
$$

The exact phonological and morphosyntactic conditions on this rule require further discussion and empirical investigation. Analogous phrasal $\mathrm{H}$ insertion between words within a phrase can be found in Kikerewe (Odden 2000a), Jita (Downing 1996), Zinza (Odden 2000b), Runyankore (Poletto 1998) and Kimatuumbi (Odden 1996). This floating $H$ then docks to the first vowel on the right.

\footnotetext{
${ }^{3}$ A reviewer suggests the possibility that the stem for 'shadow' is disyllabic $-i j u$, where vowel deletion maps $/ \mathrm{ki}$-iju/ onto [kiju]. This theory could be tested with a form selecting a prefix not ending in $i$, which unfortunately is not available in my data. Theoretically, the stem for 'face' could likewise be -ušu. Further fieldwork is required to definitively resolve this issue.
} 
(10) H-Docking

$\left.\mathrm{H}^{\prime}\right]$

$[\mu$

According to this rule, only a floating $\mathrm{H}$ docks to the next word. ${ }^{4}$ As stated in (9),

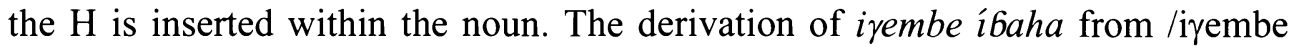
i6aha/ thus inserts a floating $\mathrm{H}$ tone into the noun i yembe by (9), and (10) then links that $\mathrm{H}^{\prime}$ to the left edge of the following adjective.

Given these rules for the variable adjectival $\mathrm{H}$, the lexically $\mathrm{H}$ nouns of (4) such as iriso must have a $\mathrm{H}$ linked to the final syllable, to maintain the behavioral distinction between irisó ibaha and irembe íbaha. If iriso had a floating $\mathrm{H}$, and if the combination of toneless noun plus adjective irembe $+i 6 a h a$ also received a floating $\mathrm{H}$, there would be no way to distinguish the behavior of toneless and $\mathrm{H}$ nouns before an adjective. If $\mathrm{H}$ nouns have a lexically-linked final $\mathrm{H}$ and a floating $\mathrm{H}$ is inserted when a toneless noun is combined with an adjective, the distinction is easily maintained via the difference between linked and floating tones.

This analysis raises the question what happens to the floating $\mathrm{H}$ in irisó ibaha (4) where the noun has a lexical final $\mathrm{H}$, or ifúmu ibaha (5) with a penult $\mathrm{H}$ ? The lack of $\mathrm{H}$ can be explained in two ways. Insertion of $\mathrm{H}$ by (9) could be constrained, to insert $\mathrm{H}$ only after a toneless noun. This would render (9) parallel to similar rules of Kikerewe and Kimatuumbi, where $\mathrm{H}$ insertion is blocked when the triggering word has a $\mathrm{H}$ tone. How to encode such a restriction on insertion is a problem of phonological theory: see Reiss (2003) for discussion of the role of existential quantifiers and variables in a formal theory of phonology. Since a formal statement of $\mathrm{H}$-tone blockage would seem to require a number of devices to express the condition $\forall x((x \in Y) \supset((x \neq H))$ - variables, quantifiers and a membership operator - which are not independently known to be part of the theory of rules, I will not adopt a blocking condition on $\mathrm{H}$ insertion. The alternative,

${ }^{4}$ Robert Botne (p.c.) suggests the alternative that such nouns have a floating $\mathrm{H}$ (as distinct from the finally-linked $\mathrm{H}$ underlying the nouns of (2b)). There is no contrast between toneless noun stems and those with floating $\mathrm{H}$, so this is conceivable; the tradeoff is that the floating $\mathrm{H}$ must be deleted in the complement of the context (9), and all nouns must be assumed to have some $\mathrm{H}$ tone. In addition, however, an alternative analysis of the tone of the copula would be necessitated if the nouns of (2a) have a floating tone, since, as I show in section 3.2, the copula has a floating tone but behaves differently from toneless nouns. 
adopted here, is an additional rule of $\mathrm{H}$ deletion, one deleting a floating $\mathrm{H}$ tone after any $\mathrm{H}$.

\section{(11) Meeussen's Rule $\mathrm{H}^{\prime} \rightarrow \varnothing / \mathrm{H}$}

I am aware of no facts showing whether restricting (9) is empirically better or worse in accounting for adjectival $\mathrm{H}$ than deletion (11). Derivations of relevant forms are given below to show how these alternations are accounted for.<smiles>CCCC</smiles>

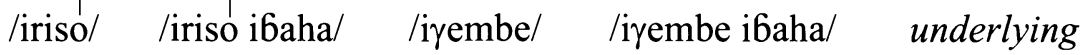

$$
\stackrel{\mathrm{iriso}}{\mathrm{H} \mathrm{H}} \mathrm{ibaha}_{\text {[iriso ibaha] }}^{\mathrm{H}}
$$

$\mathrm{H}$

iүembe ibaha $P H I(9)$

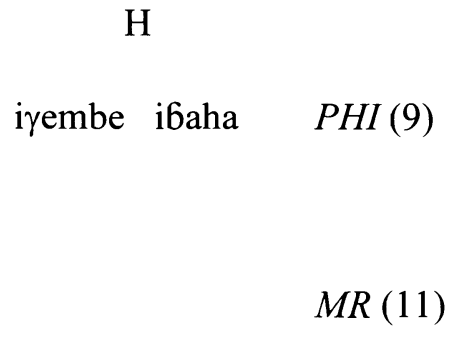

[irembe ibaha]

H-Docking (10)

[iriso]

PHD (8)

In the citation form iriso, the final $\mathrm{H}$ is simply deleted. In /irisó ibaha/ a floating $\mathrm{H}$ is inserted before the adjective, but is deleted because of the preceding $\mathrm{H}$. In

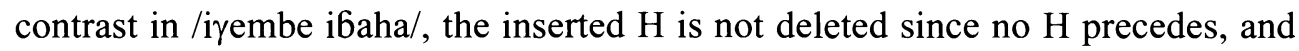
$\mathrm{H}$-Docking (10) therefore maps the $\mathrm{H}$ to the following word.

A surface complication of this pattern is encountered when the noun is in agreement class 9-10, which has a surface nonsyllabic class prefix N-. In contrast to previous examples, where the adjective's assigned $\mathrm{H}$ appears on the class prefix $\left(k i-, i\right.$-, $l u$ - etc. as well as syllabic $\left.m_{1}\right)$, when the noun and adjective are in class 9-10, the $\mathrm{H}$ appears on the root-initial syllable. With $\mathrm{H}$ nouns in (13), no $\mathrm{H}$ is ex- 
pected on the adjective because the floating $\mathrm{H}$ would be deleted due to the noun's $\mathrm{H}$ tone.
(13)

$\begin{array}{llll}\text { čoka } & \text { 'snake' } & \text { čoká ndača } & \text { 'long snake' } \\ \text { koši } & \text { 'dog' } & \text { košı mbaha } & \text { 'big dog' } \\ \text { mbanga } & \text { 'cave' } & \text { mbangá mbaha } & \text { 'big cave' } \\ \text { ngolo } & \text { 'heart' } & \text { ngoló mbaha } & \text { 'big heart' } \\ \text { nguku } & \text { 'chicken' } & \text { ngukú ndača } & \text { 'tall chicken' } \\ \text { singo } & \text { 'neck' } & \text { singó ndača } & \text { 'long neck' } \\ \text { tindi } & \text { 'tomato' } & \text { tind' mbaha } & \text { 'big tomato' }\end{array}$

Similarly, penult- $\mathrm{H}$ nouns predictably have no $\mathrm{H}$ tone assigned to the adjective.
(14) yóndi
'sheep'
jóndi mbaha
'big sheep'
ngánga
'guinea fowl'
ngánga mbaha
'big guinea fowl'
sabúni
'soap'
sabúni ndača
'long soap'

After toneless nouns, however, a $\mathrm{H}$ appears on the first syllable of the adjective root.

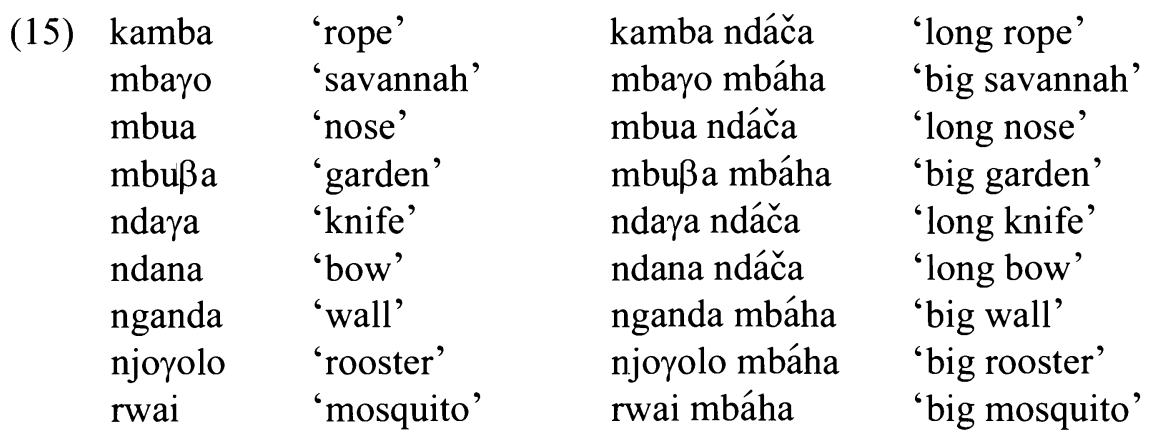

Two explanations for the position of $\mathrm{H}$ in such adjectives come to mind. First, the Class $9-10$ prefix might be underlying $/ \mathrm{n} /$ and the prefix first takes the assigned $\mathrm{H}$ tone, but later desyllabifies, causing progressive tone shift, so that intermediate ndana ńdača becomes [ndana ndáča]. The other and more direct analysis is that the class $9-10$ prefix is not a tone-bearer, and the assignment of the $\mathrm{H}$ on the root-initial syllable takes place directly, because the docking rule assigns the $\mathrm{H}$ to the first available TBU in the following word, i.e. the root-initial vowel. We will see evidence in the following section that argues that the prefix $N$ - 
is syllabic, which makes the first scenario at least plausible though it does not automatically rule out the latter analysis, given appropriate rule ordering.

The data considered so far have involved nouns plus surface-toneless adjectives. Some nominal modifiers have a root-initial $\mathrm{H}$, which creates an opportunity to observe another generalization about the language, that combinations of $\mathrm{H}$ tones are always separated by a downstep on the surface. As seen in (16), after a toneless noun, the phrasally-assigned $\mathrm{H}$ on the class prefix is separated from the root $\mathrm{H}$ by downstep.

\begin{tabular}{|c|c|c|c|c|}
\hline (16) & 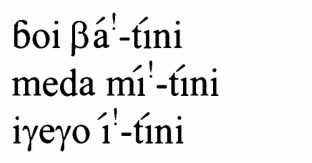 & $\begin{array}{l}\text { 'small cats' } \\
\text { 'small rivers' } \\
\text { 'small tooth' }\end{array}$ & 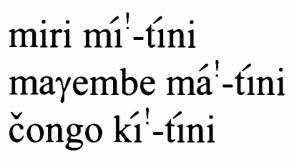 & $\begin{array}{l}\text { 'small roots' } \\
\text { 'small hoes' } \\
\text { 'small head' }\end{array}$ \\
\hline & \multicolumn{2}{|c|}{ mayembe má'-sánu'5 hoes’ } & kamba 1́!-sánu & '5 ropes' \\
\hline & vijiko ví-sánu & '5 spoons' & vikoto ví-sánu & '5 hands' \\
\hline & čwau ŕ-sánu & '5 feet' & mbußa 1'-sánu & '5 gardens' \\
\hline & $\beta$ ada $\beta$ ana $\beta a ́$-sánu & '5 youths' & ßaka ßá!-sánu & '5 women' \\
\hline
\end{tabular}

The downstep can be explained structurally by positing the representation (17).

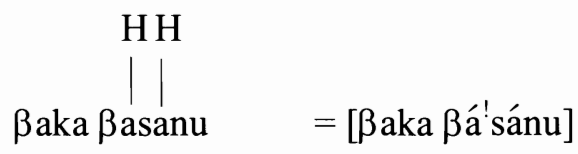

This representation is interpreted according to the convention that concatenated $\mathrm{H}$ autosegments are separated by a phonetic downstep - for further examples of Bantu languages with downsteps arising under H-concatenation, see Odden (1982) for Shambaa, Leung (1991) for Llogoori, Bickmore (2001) for Namwanga and Odden (2001) for Dembwa.

As predicted by this analysis, $\mathrm{H}$ nouns retain their $\mathrm{H}$ at the end of the noun, and no $\mathrm{H}$ appears on the adjective.
(18) kikapú ki-tı́ni 'small basket'
irisó i-t́ni
'small eye'
mikonú mi-tíni 'small arms'

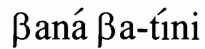
'small children'
čalá ki-tíni
'small finger'
valá vi-sánu
' 5 fingers'
čoká i-sánu
'5 snakes
čumí i-sánu
' 5 tongues'
merí i-sánu
'5 moons'
ßaná ßa-sánu ' 5 children'
ngukú i-sánu
' 5 chickens' 
While $\mathrm{H}$ and toneless nouns are usually surface-distinguishable before an adjective, just in case the adjective has a stem-initial $\mathrm{H}$ and is in class 9-10, there is tonal neutralization between the two tonal classes. The nouns in (19) have an underlying final $\mathrm{H}$ tone, which surfaces as expected, and is separated from the lexical $\mathrm{H}$ of the adjective by a downstep.

(19)

$\begin{array}{ll}\text { čoká 'ndı́ni } & \text { 'small snake' } \\ \text { ngukú !ndıni } & \text { 'small chicken' } \\ \text { tindı !ndıni } & \text { 'small tomato' }\end{array}$

koší !ndıni

singó !ndıni 'small dog'

'small neck'

Compare (19) with the toneless nouns in (20), which have the same tone pattern.

(20)
kambá 'ndini 'small rope'
ndaná 'ndini 'small bow'
nyungú 'ndini 'small pot'

mbeßá 'ndini 'small rat'

ngandá! ndini 'small wall'

Examples of penult-H nouns are given in (21) for completeness.

(21) yóndi ndíni 'small sheep'

ngánga ndini 'small guinea fowl'

The comparative derivations in (22) demonstrate that this convergence of patterns is accounted for by the rules established above.

(22)

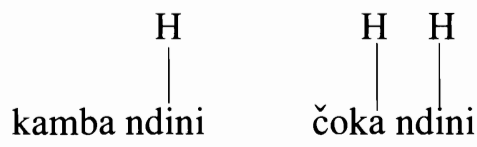

underlying

kamba ndini čoka ndini

PHI (9)

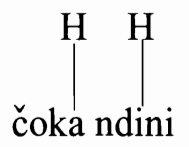

$M R(11)$ 
kamba ndini

[kambá 'ndıni] [čoká !ndı́ni]
H-Docking (10)

Surface interpretation of $\mathrm{H}+\mathrm{H}$

The explanation for surface neutralization of tone patterns here resides in the fact that with adjectives in class 9-10, there is no accessible vowel in the adjective for the inserted $\mathrm{H}$ tone to associate to.

2.2 Tonally-inert modifiers. Certain modifiers do not bear $\mathrm{H}$ after a toneless noun. Examples of two such modifiers, the numerals ' 2 ' and ' 4 ', are illustrated in (23) with $\mathrm{H}$ nouns. As expected, the underlying final $\mathrm{H}$ of $\mathrm{H}$ nouns surfaces when another word follows the noun.

(23)

$\begin{array}{ll}\beta \text { ukutá i } \beta \mathrm{i} & \text { '2 walls' } \\ \text { mikonú i } \beta \mathrm{i} & \text { '2 hands' } \\ \beta \text { aná } \beta \mathrm{a} \beta \mathrm{i} & \text { ' } 2 \text { children', } \\ \beta \text { aná bana } & \text { ' } 4 \text { children' } \\ \text { koši inya } & \text { ' } 4 \text { dogs' } \\ \text { mikamé inya } & \text { ' } 4 \text { tree }(\mathrm{sp} .)\end{array}$

$\begin{array}{ll}\text { matukú aßi } & \text { '2 days' } \\ \text { ngoló i } \beta i & \text { '2 hearts' } \\ \text { singó inya } & \text { '4 necks', } \\ \text { merí inya } & \text { '4 moons' } \\ \text { miindı inya } & \text { '4 legs' }\end{array}$

The combination of penult-H noun and one of these modifiers results in no tone changes, also as expected.
(24) mafúmu aßi
'2 spears'
mikábo ißi
'2 vertical studs'
yóndi i $\beta \mathrm{i}$
'2 sheep'
miká6o inya
'4 vertical studs'
čúmbo inya
'4 songs'
ngánga inya
'4 guinea fowls'
sabúni inya
'4 soaps'

Unexpectedly, there is no $\mathrm{H}$ tone when a toneless noun is combined with one of these modifiers. 


\begin{tabular}{|c|c|c|c|}
\hline$\beta$ uli i $\beta$ i & '2 beds' & mayo a $\beta \mathrm{i}$ & '2 stones' \\
\hline vikoto vi $\beta \mathrm{i}$ & '2 hands' & $\beta a d a \beta$ ana $\beta a \beta i$ & ' 2 youths' \\
\hline$\beta a \gamma o s i \beta a \beta i$ & '2 elders' & $\beta$ andu $\beta a \beta i$ & '2 people' \\
\hline mingulu i $\beta \mathrm{i}$ & ' 2 beans' & minyango i $\beta \mathrm{i}$ & '2 doors' \\
\hline muri i $\beta \mathrm{i}$ & '2 roots' & ndana $\mathrm{i} \beta \mathrm{i}$ & '2 bows' \\
\hline 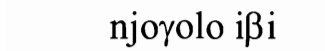 & '2 roosters' & rwai i $\beta \mathrm{i}$ & ' 2 mosquitos' \\
\hline 6oi bana & '4 cats' & mayembe ana & '4 hoes' \\
\hline mayo ana & '4 stones' & vijiko vina & '4 spoons' \\
\hline manga bana & ' 4 cassavas' & $\beta a d a \beta a n a$ 6ana & '4 youths' \\
\hline meda inya & '4 rivers' & ßaka bana & '4 women' \\
\hline minyaro inya & '4 paths' & mizi inya & '4 villages' \\
\hline
\end{tabular}

The tonal anomaly of this set of modifers is the fact that they fail to induce insertion of the phrasal $\mathrm{H}$ tone. The nouns themselves have the predicted surface form before these modifiers: penult- $\mathrm{H}$ nouns retain their penultimate $\mathrm{H}$, toneless nouns have no $\mathrm{H}$, and $\mathrm{H}$ nouns retain their final $\mathrm{H}$.

There are a number of tonally-inert modifiers. Examples of demonstratives are seen in (26) after a toneless noun.

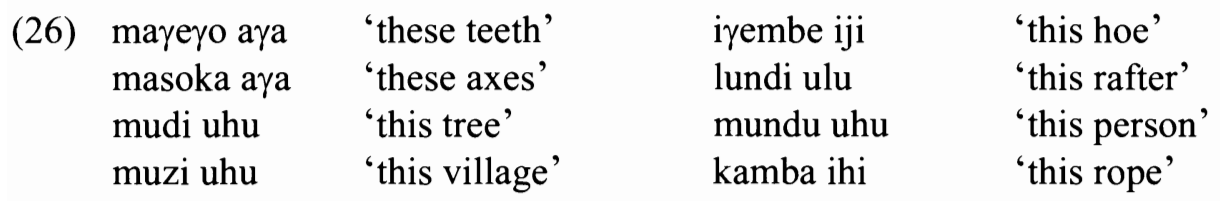

Parallel examples of $\mathrm{H}$ and penult-H nouns are seen in (27).

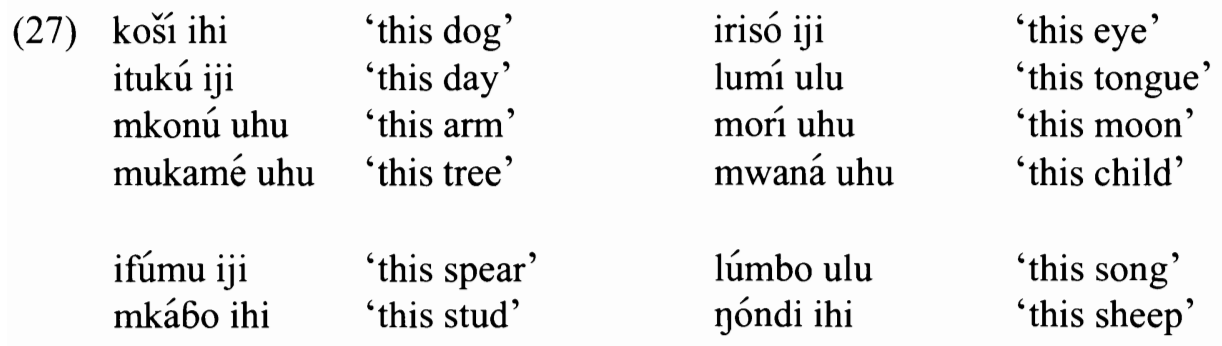

The quantifiers 'some' and 'all' have this same behavior.'

${ }^{5}$ The stem - $m$ 'some' has the phonetic characteristics of a syllabic nasal as found in various other languages, thus the $m$ of Mbololo rim is longer and is not comparable to English 
(28) a. toneless nouns $\beta a k a \beta a m$ $\beta$ ada $\beta$ ana $\beta$ am

'some women' $\beta$ andu $\beta$ am

'some youths' vikoto vim

boi $\beta$ am

ndaya rim

$\beta$ aka $\beta$ ose mbußa rose 'some cats'

'some knives'

'all women'

'all gardens' mbußa rim

masoka yam

$\beta$ andu $\beta$ ose

masoka yose 'some people'

'some hands'

'some gardens'

'some axes'

'all people'

'all axes'

b. H nouns

ßaná $\beta$ am

ngukú rim

matukú yam

'some children' vaná vim

'some chickens' mikamé im

'some days'

ßaná ßose

ngukú rose

'all children'

vaná vose

'all chickens'

c. Penult H nouns

jóndi rim

'some sheep'

mafúmu yam

'some spears'

'all sheep' 'all chicks'

'some chicks'

'some trees'

The adjective 'many' is another tonally-inert modifier.

(29) a. toneless nouns

meda nyingi

'many rivers'

minyango nyingi

mayembe mengi 'many hoes'

vikoto vingi

'many doors'

'many hands'

b. H nouns

ngukú nyingi

'many chickens' mik

matukú mengi 'many days'

c. Penult H nouns

ngóndi nyingi 'many sheep' mikábo nyingi 'many studs'

mafúmu mengi 'many spears'

'ream'. However, there is no clear phonological evidence that indicates whether this nasal should be treated as syllabic, or as a coda consonant. 
Finally, possessive pronouns fall into this category.

(30) a. toneless nouns

$\beta$ uranga $\gamma$ wapo

čangu čapo

igi japo

kijiko čapo

lundi lwapo

munyango wapo 'my medicine' $\beta$ uli $\gamma w a p o$

'my stick' ibata japo

'my egg' iyembe japo

'my spoon' kilambo čapo

'my rafter'

'my door'6

muzi $\gamma$ wapo

'my bed'

'my duck'

'my hoe'

'my thing'

'my tree'

'my village'

b. H nouns

čalá čapo

kijú čapo

mfukó wapo

ngukú yapo

mwaná wapo

c. Penult H nouns

lúmbo lwapo

msídu $\gamma$ wapo

jóndi yapo

sabúni yapo

'my finger' ibembá japo

'my shadow' koši yapo

'my bag'

'my chicken'

'my child'

munyú rwapo

singó japo

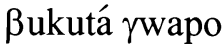

'my song' msénge rwapo

'my forest' mukábo $\gamma$ wapo

'my sheep' ngánga yapo

'my soap'

sóbo yapo 'my maize'

'my dog'

'my salt'

'my neck'

'my wall'

'my stick'

'my stud'

'my fowl'

'my stick'

Can we predict which adjectives are tonally inert and which trigger insertion of phrasal tone? The relevant factor is the length of the modifier; specifically whether it is longer than bisyllabic.

A considerable number of these modifiers are determiners, which select a special demonstrative-type set of agreement morphemes, and it is reasonable to at least suspect that the tone behavior has to do with the kind of class prefix on the modifier. For example, the nominal-type agreement for class 3 selected by both nouns and adjectives such as 'big' is $/ \mathrm{mu} /$, but the demonstrative-type agreement is $/ \gamma \mathrm{u} /$; the class 10 noun prefix is $/ \mathrm{N} /$ but the demonstrative agreement is $/ \mathrm{ji} /$.

\footnotetext{
${ }^{6}$ The form of agreement for possessives in class 3 appears to be variable, thus rwapo and wapo, the latter being the same as class 1 agreement.
} 
Careful scrutiny of the data of the previous section and this section reveals that the nature of the prefix is not the determining factor. First, the numerals ' 2 ' and ' 4 ' fall into the tonally inert class, unlike ' 1 ', ' 3 ' and ' 5 ' as well as 'how many?' which are tonally regular — see ndana ímwéri 'one bow' vs. ngoló imwéri 'one heart'; mayu á-dadu 'three legs' vs. $\beta a n a ́ ~ \beta a-d a d u$ 'three children'; mayembe má'sánu '5 hoes' vs. mesó masánu '5 eyes'; mayembe álinga 'how many hoes?' vs. marisó alinga 'how many eyes?' . But some of the numerals use this same series of agreement morphemes, the demonstrative-type prefixes (see

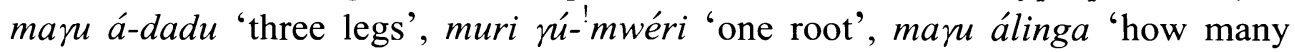
legs?'). Therefore, not all modifiers selecting the demonstrative series of agreements are tonally inert. Second, the adjective 'many' takes the nominal-type agreement - see ma-yembe m-engi 'many hoes', mbußa ny-ingi 'many gardens' - but is still tonally inert. Thus, tonal inertness is not necessarily connected with the kind of agreement morpheme (if any) used on the modifier.

The correct generalization is simply that the modifier must be longer than disyllabic in order to trigger Phrasal H Insertion. Taking the class 2 form for illustration purposes, the known tonally inert modifiers are $\beta a \beta i$ ' 2 ', 6ana '4', $a \beta a$

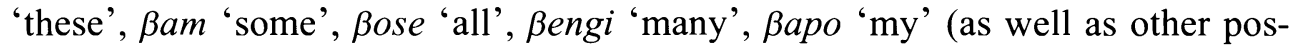
sessive pronouns) - all disyllables - and these contrast with polysyllabic modifiers which condition $\mathrm{H}$ insertion, such as the numerous adjectives and longer numerals such as $\beta a$-6aha 'big', $\beta a$-tini 'small', $\beta a$-lača 'long', $\beta a$-vui 'short', $\beta a$-rifu 'thick', $\beta a$-dadu 'three', $\beta a$-sánu '5', $\beta$ unyanya '8' and $\beta a$-linga 'how many'. 8

Presumably, the distinction between tonally-inert and tonally-regular modifiers historically correlated more tightly with the adjective vs. demonstrative distinction. The inserted $\mathrm{H}$ tone is most likely a reflex of the so-called pre-prefix, a $\mathrm{H}$-toned prefix that often appears before the noun class prefix in nouns and adjectives (but not determiners), so that the historical antecedents of [ $\beta$ andu ßálača] 'tall people' and [ $\beta$ andu $\beta \mathrm{am}]$ 'some people' were probably something like

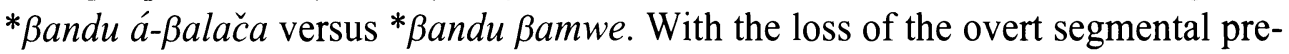

\footnotetext{
${ }^{7}$ The noun 'eye' has two plural forms, meso and mariso, the latter on analogy to singular iriso. ${ }^{8}$ It should be noted that the determination of syllable count is not a strictly surface matter since, as we have seen in the previous section, the class prefix $\mathrm{N}$ - for class 9-10 is not surface syllabic, thus especially contrast muzi ḿ-6aha 'big village (cl. 3)' versus mbußa mbáha 'big garden (cl. 9)'. It is assumed that the class 9-10 prefix is - if preconsonantal - syllabic at the stage in the derivation where Phrasal $\mathrm{H}$ Insertion applies. But the same prefix is prevocalically desyllabified before Phrasal H Insertion applies in mbußa ny-ingi 'many gardens'. My data do not include any other vowel-initial adjective stems.
} 
prefix, assuming that the tone was preserved as a floating tone that associated with the preceding noun, the puzzle would have arisen as to what the conditions are for appearance of this $\mathrm{H}$. Since the vast majority of adjectives were polysyllabic and the vast majority of determiners were disyllabic, it should not be surprising that a historically incorrect alternative generalization was uncovered by learners of the language, which, when adopted, would have led to analogical extension of the restriction to the numbers ' 2 ' and ' 4 ' as well as the adjective 'many'.

Synchronically there are any number of ways formally to express the disyllabic exclusion, for example Phrasal H Insertion rule (9) might be restricted so that the triggering modifier must contain more than three syllables; or, a special deletion rule could delete a floating $\mathrm{H}$ before a disyllabic modifier. One might even consider cliticizing disyllabic modifiers onto the head noun, as in the Kanerva 1990 account of Chichewa, which combines certain modifiers with their head nouns into a single phonological word, so that the necessary phonological word-plus-word configuration necessary for (9) does not arise. There being no compelling basis for selecting a specific account of surface failure of $\mathrm{H}$ insertion, this will be left as an area for future research.

2.3 Noun plus verb. The morphosyntactic conditions on phrasal $H$ have not been investigated in depth. However, it is clear from the available data that the rule only operates within the noun phrase. The following examples of toneless noun plus verb show that no $\mathrm{H}$ is inserted in this context.
(31) mayembe yáguye
'hoes fell'
njoyolo yéegwa
ndaya rápotokie
'a rooster fell'
$\beta$ andu $\beta$ éegwa
midi yáguye
'knives fell'
munyango góogwa
'people fell'
ßaka ßálimie
'trees fell'
boi ßéegwa
'the door fell'
'women cultivated'
'the cats fell'

As expected, the underlying final $\mathrm{H}$ of $\mathrm{H}$ nouns surfaces before a verb. 
(32) košı 'yáguye ßasa $\beta$ ' ' $\beta$ éegwa

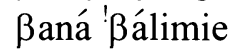

$\beta$ aná 'ßéegwa

košı !yéegwa 'a dog fell'

'witches fell'

'children cultivated'

'children fell'

'a dog fell'

Finally, penult- $\mathrm{H}$ nouns retain their $\mathrm{H}$ on the penult.

(33)

$$
\begin{aligned}
& \text { ngánga yéegwa } \\
& \text { sabúni yápotokie } \\
& \text { ifúmu jéegwa } \\
& \text { mafúmu yápotokie }
\end{aligned}
$$

'a guinea fowl fell'

'soap fell'

'a spear fell'

'spears fell'

All available data with $\mathrm{N}+\mathrm{V}$ sentences have a $\mathrm{H}$ tone on the subject prefix, making it impossible to separate that phonological fact from the syntactic distinction between verbs and adjectives, in explaining lack of tone insertion. As noted previously, a number of Bantu languages including Kikerewe, Jita, Zinza, Runyankore and Kimatuumbi have a similar morphosyntactically-conditioned $\mathrm{H}$ insertion process operating only within the NP.

This section has shown the essential characteristics of tone in nouns and noun phrases: there is an opaque contrast between underlyingly toneless stems and those with a final $\mathrm{H}$ tone, the latter $\mathrm{H}$ being deleted pre-pausally. In the presence of a modifier with more than two syllables, a floating $\mathrm{H}$ is inserted in a noun (though insertion is only evident when the noun is toneless, due to Meeussen's Rule), which then docks to the modifier if possible, otherwise docking to the final vowel of the noun.

\section{Verbal Tone.}

Issues of verb tone in Mbololo center around two questions: first, what are the factors that determine the pattern of verbs in their citation forms, and second, under what conditions does a $\mathrm{H}$ shift from a verb to a following object. The first question is motivated by the fact that Mbololo has rightward tone shifting (which is not evident from noun tonology) as well as prepausal deletion of $\mathrm{H}$ which leads to opaque alternations, and the second question is motivated by the fact that postverbal objects sometimes, but not always, receive a $\mathrm{H}$ tone after a verb, so again we want to know what facts cause the appearance of $\mathrm{H}$ on objects - properties both of the verb and of the noun are relevant to answering that question. 
3.1 Citation tone. As in most Bantu languages, Mbololo has two tone classes of verb roots, $\mathrm{H}$ and toneless. Toneless roots, in $(34 \mathrm{a})$, have no $\mathrm{H}$, regardless of word length. $\mathrm{H}$ roots, in $(34 \mathrm{~b})$, have no $\mathrm{H}$ if the root-initial syllable is word final, $\mathrm{H}$ on the root-initial syllable if that is the penult, and otherwise have $\mathrm{H}$ on the second syllable of the stem.

a. toneless roots

\begin{tabular}{|c|c|c|c|}
\hline ku-gw-a & 'to fall' & ku-šs-a & 'to grind' \\
\hline ku-lal-a & 'to sleep' & ku-sek-a & 'to laugh' \\
\hline ku-lil-a & 'to cry' & & \\
\hline ku-ziyan-a & 'to unlock' & ku-dumbu-a & 'to slice' \\
\hline ku-ruku-a & 'to unearth' & & \\
\hline
\end{tabular}

b. H roots

\begin{tabular}{|c|c|c|c|}
\hline$k u-j-a$ & 'to eat' & ku-nyw-a & 'to drink' \\
\hline ku-ßón-a & 'to see' & ku-dék-a & 'to cook' \\
\hline ku-tál-a & 'to count' & ku-dém-a & 'to chop' \\
\hline ku-sikír-a & 'to hear' & ku-layáy-a & 'to be lost' \\
\hline ku-zoүú-a & 'to pay' & ku-dafún-a & 'to chew' \\
\hline
\end{tabular}

The pattern of toneless verbs requires little comment: there is no underlying $\mathrm{H}$ so none appears on the surface. The pattern of $\mathrm{H}$ verbs is generally consistent with the assumption that the $\mathrm{H}$ is underlyingly on the first vowel of the stem, where it surfaces in forms such as kußóna. The absence of $\mathrm{H}$ in /kujá/ $\rightarrow$ [kuja] is explicable given the lack of surface final $\mathrm{H}$ in the language: I will consider the exact mechanism for deriving toneless [kuja] in section 3.2.

Affixation provides evidence for an underlying distinction between $\mathrm{H}$ and toneless monosyllabic stems, which is surface-neutralized in CV stems. When a $\mathrm{H}$ root is followed by an affix, the stem is disyllabic and therefore the stem-initial $\mathrm{H}$ is not also word-final, so it is not subject to Prepausal H Deletion (8). 
(35) a. toneless verbs

$\begin{array}{ll}\text { ku-guša } & \text { 'to make fall' } \\ \text { ku-šea } & \text { 'to grind for' }\end{array}$

b. $H$ verbs

$\begin{array}{ll}\text { ku-jısa } & \text { 'to feed' } \\ \text { ku-nyóša } & \text { 'to water' }\end{array}$

The affixed forms above indicate that there is an underlying $\mathrm{H} /$ toneless contrast in CV stems as well.

The appearance of $\mathrm{H}$ on the second stem syllable of forms such as $k u$ dafúna is indicative of a process of tone shift, which is found in various Bantu languages, including Nyamwezi, Jita and Dembwa, where $\mathrm{H}$ shifts one syllable to the right from /ku-dáfuna/. This rightward shift is also motivated by paradigmatic alternations. Examples of toneless verbs such as $k u$-lim-i-a 'to cultivate for', $k u$ sek-e- $a$ 'to laugh for' and ku-lip-an-a 'to pay each other' show that the applied and reciprocal affixes $-i$ - and - an- contribute no $H$ tone. Data in (36) show shifting of the root $\mathrm{H}$ to the second stem syllable, compared to the unshifted rootinitial position of disyllabic $\mathrm{H}$ stems.
(36) ku-ßon-án-a
'to see e.o'
(kußóna 'to see')
ku-dek-é-a
'to cook for'
(kudéka 'to cook')
ku-tal-1-a
'to count for'
(kutála 'to count')
ku-bor-é-a
'to sing for'
(kubóra 'to sing')

Furthermore, the data in (37) show that regardless of the number of syllables which follow, $\mathrm{H}$ shifts by only one syllable, i.e. this is a bounded process of shifting and not unbounded shift as in Digo (see Kisseberth 1984).
(37) ku-tem-ér-e-a
'to cut for'
ku-dek-é-an-a
'to cook for e.o'
ku-tal-1-an-a
'to count for e.o.'
ku-om-éš-er-an-a
'to dry for e.o'

As observed in Kisseberth \& Odden (2003), there are often two conceivable approaches to tone shifting in languages, on one hand positing a direct shifting rule which moves $\mathrm{H}$ from its input position, on the other hand accomplishing shift by separate steps of spreading followed by delinking of multiply-linked $\mathrm{H}$ 
tones. The idea behind the two-step approach is that languages with tone shift strongly tend not to have multiply-linked $\mathrm{H}$, which may allow shift to be handled by independently motivated tone processes. Odden (2001) argues for a spreadand-delink approach to Dembwa tone, based on the fact that the contexts where $\mathrm{H}$ spreads are much broader than the contexts where multiply-linked $\mathrm{H}$ delinks. Thus in Dembwa, we find only spreading in /kudéka/ $\rightarrow$ [kudééká] 'to cook' and /kudékia/ $\rightarrow$ [kudékíia] 'to cook for', but spreading and delinking in /kudékiana/ $\rightarrow$ [kudekíaana] 'to cook for each other' and /kudékia $\beta$ andu/ $\rightarrow$ [kudekiá ßaandu] 'to cook for people'.

Such an argument is not forthcoming in Mbololo. There seem to be no multiply-linked $\mathrm{H}$ tones in the language - no surface $\mathrm{HH}$ sequences. ${ }^{9}$ Consequently a direct-shifting rule such as in (38) is empirically viable.

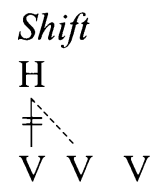

The inclusion of a vowel to the right encodes the restriction that the target of shifting cannot be word final, so that Shift does not apply to /kußóna/. An alternative would be the pair of rules, Spread and Delink.

(39)

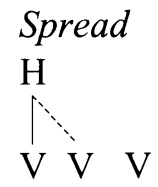

Delink

$\mathrm{H}$

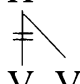

There being no facts suggesting an empirical advantage to either account synchronically, I assume the shifting account on the grounds of simplicity and greater concreteness, regardless of the fact that tone shift no doubt arises historically

${ }^{9}$ My notes do contain some transcriptions of the type [ßállúmáne] 'they bit each other' from / $\beta$ á-lúmane/ along with [ $\beta$ 1́sikíriana] 'they will hear each other' from / $\beta$ 1́-síkiriana/. These pronunciations seem to be in free variation, with the latter HLH pronunciation being more frequent. Pending a deeper phonetic investigation of surface ...HLH... sequences, I conclude that forms such as [ $\beta$ állúmáne] are the result of a low-level phonetic tonal interpolation which raises $F_{0}$ in a $L$ syllable between $H s$, a process known in many tone languages (Hyman 1978) and especially in Kipare (Odden 1985), a language geographically close to Taita. 
from the convergence of tone spread and tone delinking. ${ }^{10}$ The fact that neither spreading nor shifting targets the final vowel may also have a connection to the loss of pre-pausal $\mathrm{H}$ tones, but these non-finality facts are not the same fact since $\mathrm{H}$ deletion only deletes prepausal $\mathrm{H}$, whereas shift / spread is restricted from applying to a word-final vowel regardless of phrasal context (see ni-déka mabemba 'I will cook maize'). See Kisseberth \& Odden (2003) for discussion of the various manifestations of nonfinality in Bantu.

Another context for tone shift is the combination of object prefix and toneless stem. As (40) shows, the toneless stem -lela receives a $\mathrm{H}$ tone when an object prefix precedes, which is explained by the assumption that object prefixes have $\mathrm{H}$ tone, which is subject to bounded rightward shift. As expected, the $\mathrm{H}$ of the OP shifts only to the immediately following syllable.

$\begin{array}{ll}\text { (40) ku-lela } & \text { 'to raise a child' } \\ \text { ku-ni-léla } & \text { 'to raise me' } \\ \text { ku-di-léla } & \text { 'to raise us' } \\ \text { ku-ziyana } & \text { 'to look at' } \\ \text { ku-ni-źryana } & \text { 'to look at me' }\end{array}$

Consideration of $\mathrm{H}$-toned verbs with an object prefix reveals evidence for a rule of $\mathrm{H}$ tone deletion, since such verbs present two underlying $\mathrm{H}$ tones but only one surface $H$. As we see in (41), the only surface $H$ appears where it would be expected to, given just the $\mathrm{H}$ of the root: on the penult of disyllabic verbs and the second syllable of longer verbs. In fact, there is at most a single $\mathrm{H}$ on the macrostem, the morphological constituent composed of object prefixes plus the traditional stem.

\footnotetext{
${ }^{10}$ As has been repeatedly emphasized in the history of linguistic theory, simplicity cannot be decided in a theoretical vacuum. An alternative theoretical consideration is that the single rule may require a "two-action" formulation of association insertion and deletion, running afoul of the "single node" conjecture assumed in numerous autosegmental works such as Clements (1985), namely that rules should be restricted to a single simple operation. Whether shift must be expressed formally as two distinct operations, or instead represents a single primitive operation of movement, is a highly abstract theoretical question, one which is orthogonal to the purpose of this paper.
} 


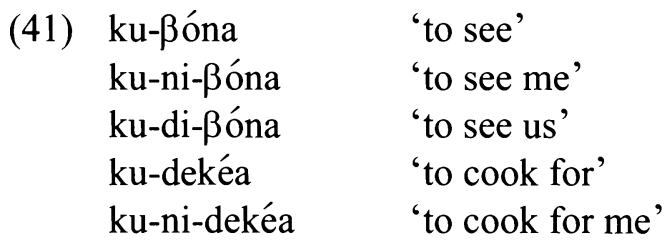

This raises two possibilities. One is that the $\mathrm{H}$ of the object prefix deletes before the $\mathrm{H}$ of a verb stem by "reverse Meeussen's Rule", and the H which survives is then shifted (when applicable, i.e. when the second $H$ is not in the penult) to the following syllable.

(42)

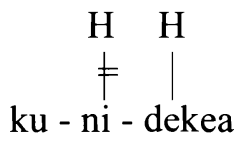

ku - ni - dekea
Reverse $M R$

Shift

An alternative is that the two $\mathrm{H}$ tones merge, resulting in a doubly-linked $\mathrm{H}$.

(43)

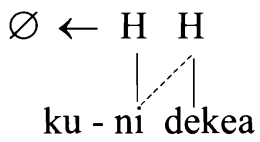

Subsequently, the H may spread further to the right, but only the final tone association is preserved on the surface, and the multiply linked $\mathrm{H}$ then is delinked from the left. This second approach to $\mathrm{H}$ sequences in the macrostem would render more plausible the two-step approach of spreading and delinking, by showing that the delinking process has independent motivation. Since it is not evident that there has to be a process of tone fusion rather than direct tone deletion, we cannot draw any strong conclusions based on these data.

There is a contrast in subject prefixes between the third person prefixes, which have $\mathrm{H}$ tone, and first and second person which have no $\mathrm{H}$. This $\mathrm{H}$ neither shifts nor deletes, as shown by the following data. 
(44) $H$ verbs

$$
\text { ni-ja }
$$

ú-ja

ni-déka

ú-déka

di-déka

ßí-déka

na-jıe

wá!-jıe

da-lumáne

ßá-lumáne
'I will eat'

'he will eat'

'I will cook'

'he will cook'

'we will cook'

'they will cook' toneless verbs

ni-gwa

ú-gwa

ni-lima

ú-lima

di-lima

$\beta^{\prime}$-lima

na-šsie

wá-šie

na-dirie

ßá-dirie
'I will fall'

'he will fall'

'I will cultivate'

'he will cultivate'

'we will cultivate'

'they will cultivate'

'I ground'

'he ground'

'I poured'

'they poured'

The lack of any tone shifting, especially in toneless verbs, where one might expect the $\mathrm{H}$ tone of the subject prefix to shift to the root initial position, can be explained by restricting shift to applying only within the macrostem and not across the macrostem boundary. Similarly, the fusion or deletion process that eliminates the $\mathrm{H}$ of the object prefix in /ku-ni-dékea/ is restricted to applying just within the macrostem. The presence of downstep in $\beta{ }^{\prime}$ '-déka 'they will cook' and wá-jíe 'he ate' is predicted under the assumed principle of phonetic interpretation whereby a downstep appears between any two surface-concatenated $\mathrm{H}$ tones.

An additional tone pattern is found in verbs, illustrated below in the negative imperative, where verbs lack $\mathrm{H}$ tones altogether. ${ }^{1}$

\begin{tabular}{llll} 
H stems & \multicolumn{2}{l}{ toneless stems } \\
kse-je & 'don't eat!' & kse-še & 'don't grind!' \\
kse-deke 'don't cook!' & kse-lime 'don't cultivate!' \\
mse-lumane 'don't (pl) bite e.o.!' & kse-dumbuo 'don't slice!'
\end{tabular}

The analysis of these forms will be taken up in the next section, since revealing evidence also comes from their phrasal behavior.

${ }^{11}$ The initial [ks] cluster is typologically odd since Taita does not generally allow initial obstruent clusters, and on comparative grounds we would expect [kusedeke] etc. I have never recorded an audible vowel in such examples, but it is possible that under some condition the vowel is phonetically manifested. 
3.2. Copula + Noun. The combination of verb plus object does not, in and of itself, give rise to tone alternations; as can be seen in (46), the lexical $\mathrm{H}$ of a $\mathrm{H}$ verb root remains in the expected stem-initial position before an object, the object's tone is unaffected by the preceding verb, and in particular the combination of a toneless verb plus a toneless object does not lead to insertion of any $\mathrm{H}$.

(46) ku-tála ßalimi

'to count farmers'

ku-rukua miri

'to dig up roots'

Contrast the lack of inserted $\mathrm{H}$ in kurukua miri with the fact that $\mathrm{H}$ is inserted in an analogous NP structure masoka málača 'long axes' from /masoka malača/.

Under certain circumstances, the combination of verb plus complement noun results in the appearance of an unexpected $\mathrm{H}$. These data provide evidence for a $\mathrm{H}$ tone which is underlyingly part of the copula, and shifts into a following noun. The phonological conditions on verbal complements can be clearly illustrated with the copula $n i$. The data in (47) show that a $\mathrm{H}$ is assigned to the first vowel of a noun after $n i$.

a. toneless nouns

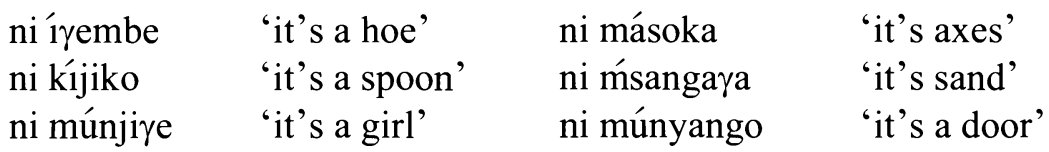

b. H nouns
ni írina
'it's a name'
ni kídasi
'it's a basket'
ni ḿfuko
'it's a bag'
ni ḿkonu
'it's a hand'

These data suggest either a floating tone as part of the lexical representation of the copula, or an associated $\mathrm{H}$ - that is, either (48a) or (48b).

(48) a. H

$\mathrm{n} \mathrm{i}$ b. $\mathrm{H}$

$\mathrm{ni}$

This $\mathrm{H}$ then appears on the noun by a mechanism similar or identical to that needed for toneless noun plus modifier. Choosing between these representations is not easy, but I assume the linked tone account, and discuss evidence later. 
The data in (49) show the copula plus nouns with penult $\mathrm{H}$, where $\mathrm{H}$ is assigned after the copula on the first syllable of the noun, separated from any immediately following $\mathrm{H}$ by a downstep.
(49)
$\begin{array}{ll}\text { ni má! fúmu } & \text { 'it's a spear' } \\ \text { ni mí'sídu } & \text { 'it's forests' }\end{array}$
ni mú'kábo
'it's a vertical stud'
ni ḱsserére
'it's salt'

These forms are parallel to (16) with toneless $\mathrm{N}$ plus adjective with $\mathrm{H}$ on the sec-

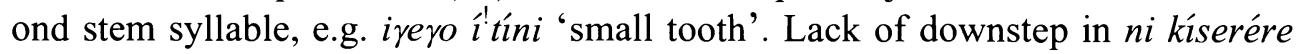
'it's salt' is due to the intervening syllable between the copula and lexical Hs.

The examples considered so far have involved nouns in classes other than 9-10, which have a surface prefix with a vowel. As (50) shows, the $\mathrm{H}$ appears on the first noun-stem syllable when the noun is class 9-10, again separated by a downstep from any adjacent $\mathrm{H}$ in the stem.

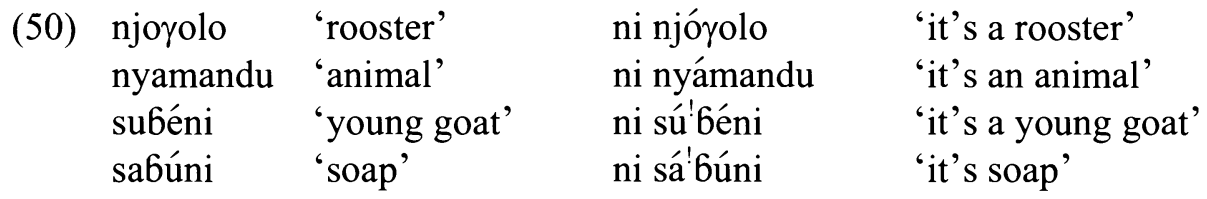

This again parallels the pattern of $\mathrm{H}$ inserted after toneless nouns: the $\mathrm{H}$ appears on the first syllable of the following word, regardless of whether it is a prefix or stem syllable.

The preceding data include only trisyllabic or longer nouns: disyllabic nouns are different. The data of (51) present no problem, being composed of disyllabic toneless nouns. The data on the left motivate the conclusion that these nouns are lexically toneless, as shown by their lack of $\mathrm{H}$ before an adjective and conditioning of a $\mathrm{H}$ on the following adjective by Phrasal $\mathrm{H}$-Insertion (9). The data on the right show $\mathrm{H}$ shifted from the copula to the beginning of that noun.

(51) N+modifier

čangu kílača

čia ßúnyanya

kamba ndáča

mayo a $\beta$ i

mundu múlača

nombe $\beta$ únyanya

nyumba $\beta$ únyanya ' 8 houses' copula $+N$

ni čángu

ni čía

ni kámba

ni máyo

ni múndu

ni jómbe

ni nyúmba 'it's a stick'

'it's a path'

'it's a rope'

'it's stone'

'it's a person'

'it's a cow'

'it's a house' 
We now turn to two complications.

Examples of penult-H nouns preceded by $n i$ are given in (52).

\section{(52)}

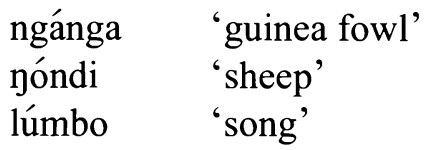

ni ngánga

ni yóndi

ni lúmbo 'it's a guinea fowl'

'it's sheep'

'it's a song'

It is perhaps not surprising that these forms surface as such. If the $\mathrm{H}$ were to link to the following noun, it would be automatically absorbed by the $\mathrm{H}$ which is already there. But contrast the disappearance of $\mathrm{H}$ in (52) with data such as [mbeßá 'ndini] 'small rat' which involve a toneless $\mathrm{N}$ undergoing Phrasal H Insertion (9), where the floating $\mathrm{H}$ is linked to the last vowel of the preceding noun. We would have analogously expected *ní 'ngánga — why does H not appear on the copula?

As shown in (53), the $\mathrm{H}$ of the copula is manifested on the copula (rather than appearing on the following noun, or being deleted) when the word-initial target syllable in the noun stands immediately before an underlying word-final $\mathrm{H}$, that is with /cvcŕ/ nouns. The examples on the left show that these nouns have underlying final $\mathrm{H}$, and those on the right show that the copula's $\mathrm{H}$ does not shift to the noun, as would have been expected.

$\begin{array}{llll}\text { (53) čalá kilača } & \text { 'long finger' } & \text { ní čala } & \text { 'it's a finger' } \\ \text { kijú kibaha } & \text { 'big shadow' } & \text { ní kiju } & \text { 'it's a shadow' } \\ \text { koší mbaha } & \text { 'big dog' } & \text { ní koši } & \text { 'it's a dog' } \\ \text { mači } \text { yapo } & \text { 'my water' } & \text { ní mači } & \text { 'it's water' } \\ \text { mbuŕ } \beta \text { unyanya } & \text { '8 goats' } & \text { ní mburi } & \text { 'it's a goat' } \\ \text { moŕ mbaha } & \text { 'big moon' } & \text { ní mori } & \text { 'it's the moon' } \\ \text { ngoló mbaha } & \text { 'big heart' } & \text { ní ngolo } & \text { 'it's a heart' } \\ \text { tindi } \beta \text { unyanya } & \text { '8 tomatos' } & \text { ní tindi } & \text { 'it's a tomato' }\end{array}$

Penult-H data like [ni mú'kábo] shows that the restriction against H-shifting from the copula is not simply due to the fact of there being a following $\mathrm{H}$ : rather, it is a final $\mathrm{H}$ that blocks tone shift. Descriptively, we can say that a $\mathrm{H}$ is blocked from associating to a vowel before a final $\mathrm{H}$, or that it is blocked from associating to a stressed vowel before a $\mathrm{H}$, insofar as penult stress is automatic in the language.

Assuming that the copula has an underlying floating $\mathrm{H}$, it is not surprising for it to behave somewhat differently from nouns discussed in section 2 , since no nouns have an underlying floating $\mathrm{H}$. The synchronic data do not point to any 
well-founded conclusions as to why noun plus modifier behave differently from verb plus complement, but it can be speculated that the explanation for this difference has to do with the different historical origins of the floating $H$. The phenomena in question - blockage of $\mathrm{H}$ association and deletion of $\mathrm{H}$ - are instances of a common tonal pattern found in Bantu, namely the avoidance of $\mathrm{H}+\mathrm{H}$ sequences (compliance with the Obligatory Contour Principle). We can easily reconstruct pre-shift forms along the lines of *ní ngoló, *ní ngángá and *ní mundu, which appear contemporarily as ní ngoló, ni ngánga and ni múndu. The case of * ní ngángá represents straightforward application of reverse Meeussen's rule deletion of $\mathrm{H}$ before adjacent $\mathrm{H}$. Failure of tone shift in *ní ngoló is comprehensible as blockage of tone shift due to the OCP, and ni múndu is the result of unobstructed tone shift. But we also know that simple OCP blockage cannot be the synchronic explanation for ní ngolo, since when the target syllable in the next word is followed by a non-final $\mathrm{H}$ - /ní subéni/ $\rightarrow$ ni sú! Géni 'it's a young goat' - shifting does in fact take place.

It was noted above in connection with (41) that regressive deletion of $\mathrm{H}$ before $\mathrm{H}$ is motivated within the word in Mbololo, since the $\mathrm{H}$ tone of an object prefix deletes in /ku-d1-ßóna/ -> [kudißóna] 'to see us'. Because there is no deletion of $\mathrm{H}$ in a subject prefix ([ú'-déka] 'he will cook'), regressive deletion must be restricted within the word to the macrostem domain (the subword composed of the stem plus any object prefix). Yet we also see a phrase-level instance of this same process in /ń ngánga/ -> [ni ngánga]. This is theoretically problematic if these are instances of the same rule, because the domain where regressive $\mathrm{H}$ deletion applies would be discontinuous - the macrostem but not the word, and the VP but not the NP. The connection between these domains becomes more obvious when you consider the historical structural parallelism between object prefix and verb, and verb plus complement - both involve VP-internal structures, that is, the domain of regressive deletion rule is something about the verb.

Synchronically, the divergence of the shifting H of the NP and the shifting $\mathrm{H}$ of the VP does not follow automatically from any representational assumption, most obviously the distinction between linked and floating $\mathrm{H}$. In the NP, as we have seen, linked final $\mathrm{H}$ tones do not shift into modifiers and floating $\mathrm{H}$ 's do, but floating H's in NP do not delete before CV́CV modifiers, so the analogy with NP tonology is close but imperfect.

3.3 Verb + Noun. The emergence of $H$ tones on a word following a verb is not restricted to the copula. The same phenomenon is encountered with the combination of a monosyllabic $\mathrm{H}$ stem plus an object. Drawing on examples in the pres- 
ent-future tense, (54a) shows that objects receive no $\mathrm{H}$ when preceded by a toneless verb. Similarly after disyllabic $H$ toned verbs in $(54 b)$, there is no $H$ on the object. But in (54c) we see that the initial vowel of the object receives $\mathrm{H}$ after an underlyingly monosyllabic $\mathrm{H}$ verb.

a. ni-ša mabemba ú-ša mabemba ni-lima mabemba ú-lima mabemba

b. ni-déka mabemba ú-déka mabemba

c. ni-ja mábemba ú-ja mábemba
'I will grind maize'

'he will grind maize'

'I will cultivate maize'

'he will cultivate maize'

'I will cook maize'

'he will cook maize'

'I will eat maize'

'he will eat maize'

The appearance of a $\mathrm{H}$ on an object after a $\mathrm{H}$-toned $\mathrm{CV}$ stem makes sense in light of the fact demonstrated above that tones also shift from the copula to a following noun. What must be clarified is why $\mathrm{H}$ shifts into the object only after a $\mathrm{H}$-toned $\mathrm{CV}$ stem. The obvious answer is that since lexical $\mathrm{H}$ is assigned to the first vowel of the stem, in a CV stem the $\mathrm{H}$ tone would appear on the final vowel, and thus we have shifting from a word-final vowel into the following noun, thus [nija mábemba] derives from /ni-já mabemba/.

Further data show full parallelism with post-copular tone. The $\mathrm{H}$ toned $\mathrm{CV}$ stems in (55) show that the $\mathrm{H}$ shifts into a disyllabic toneless stem, but not into a stem with final $\mathrm{H}$. The data in (55a) illustrate toneless stems and those in (55b) illustrate final $\mathrm{H}$; the data on the right motivate the assignment of these nouns to the toneless vs. $\mathrm{H}$ class.
a. ni-ja mánga
'I will eat cassava' ni-nywa čófi ni-ja mági
'I will drink beer'
'I will eat eggs'

manga bana

'4 cassava'

b. ni-nywá mači

'I will drink water' ni-nywá $\beta$ uki

'I will drink honey'

čofi ßúnyanya

magi mábaha

mačí aga

Bukí uru
' 8 beers'

'big eggs'

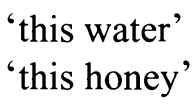


The forms ni mánga 'it is a cassava', ni čófi 'it is beer' versus ní mači 'it is water', ní $\beta u k i$ 'it is honey' show the parallelism between monosyllabic $\mathrm{H}$ verbs and the copula.

We encounter this pattern in other tenses as well, with the conditional in (56a), the recent past in (56b), the future in (56c) and the infinitive in (56d). In these cases, toneless stems regardless of length contribute no $\mathrm{H}$, nor do polysyllabic $\mathrm{H}$ stems, but monosyllabic $\mathrm{H}$ stems trigger appearance of $\mathrm{H}$ at the beginning of the noun (or end of the verb, in case the noun is /cvcŕ/).

a. nika-tála mabemba nika-gua mabemba nika-ša mabemba nika-ja mábemba

b. na-tála mabemba na-lima mabemba na-ša mabemba na-ja mábemba

c. niča-tála mabemba niča-lima mabemba niča-ša mabemba niča-ja mábemba niča-nywá mači

d. ku-tála mabemba ku-lima mabemba ku-nywa čófi
'if I count maize'
'if I buy maize'
'if I grind maize'
'if I eat maize'

'I will count maize'

'I will cultivate maize'

'I will grind maize'

'I will eat maize'

'I will drink water'

'to count maize'

'to cultivate maize'

'to drink beer'

As pointed out in (45), certain tenses in Mbololo render the verb surface toneless, examples being repeated below.

(57) H stems kse-je kse-deke mse-lumane 'don't bite e.o.!' toneless stems

kse-še 'don't grind!'

kse-lime 'don't cultivate!'

kse-dumbuo 'don't slice!' 
It is common for Bantu languages to make a distinction between tenses where only the lexical $\mathrm{H} /$ toneless root distinction (interacting with general phonological principles of the language) determines tone, versus those where an additional $\mathrm{H}$ tone is added to the stem. The pattern of (57) is an opaque reflex of this original system, where $\mathrm{H}$ was added to the stem in certain tense-aspect categories. This $\mathrm{H}$ often appears on the final vowel of the stem (for example in Kikamba, Ekegusii, and the Luhya languages) or varies between the final vowel vs. the second stem vowel, depending on the lexical tone of the root (e.g. Shona and most Rutara languages). One property often associated with this melodic $\mathrm{H}$ is that it conditions deletion of preceding $\mathrm{H}$ tones within the stem or word, a property found throughout Rutara and Luhya. The data in (59), from the Luhya language Tachoni, illustrate both the melodic $\mathrm{H}$ and the deletion of lexical $\mathrm{H}$ conditioned by the melodic $\mathrm{H}$. In Tachoni, the melodic $\mathrm{H}$ does not surface on the word-final vowel; it spreads to the left, the position being determined by the lexical tone (to the second syllable when the root is toneless, to the third syllable when the root is $\mathrm{H}$-toned). The first two examples illustrate the contrast between the exclusively lexical tonebased pattern of the infinitive in a toneless verb versus the melodic $\mathrm{H}$ of the (near) future tense. The second two examples illustrate the pattern of $\mathrm{H}$ verbs; note in the last example that a lexical $\mathrm{H}$ is deleted in the presence of the melodic $\mathrm{H}$.

(58) oxu-sukuwanila bali-sukúwáníla oxu-bótooxananila bali-botooxánáníla 'to scrape for each other'

'they will scrape for each other'

'to go for each other'

'they will go for e.o.'

Mbololo forms such as mse-lumane presumably reflect earlier mse-lúmané with deletion of the lexical tone due to the melodic $\mathrm{H}$, and then deletion of the melodic $\mathrm{H}$ itself because it is word-final.

Phrasal data support this account of the all-toneless pattern for Mbololo, since these tenses have the additional quirk of causing assignment of $\mathrm{H}$ to a following object noun, with the expected further complication that disyllabic $\mathrm{H}$-final nouns block this tone shift, and realize the $\mathrm{H}$ on the final vowel of the verb. Note that $\mathrm{H}$ appears after the verb (or at the end of the verb when followed by a CV́CV noun) regardless of the lexical tone or syllable count of the stem. 


\section{(59) H verbs kse-tale ßálimi 'don't count farmers!' kse-tale míri 'don't count roots!' kse-talé koši 'don't count dogs!' (/koši/)}

Toneless kse-kumbe mágo 'don't throw eggs!' verbs kse-kumbe ndága 'don't throw knives!' kse-kumbé tindi 'don’t throw a tomato!' (/tindr/)

To summarize, this section has shown that verbs provide further evidence for deletion of final $\mathrm{H}$, a process motivated from noun alternations as well. A synchronic shifting process is motivated which moves a $\mathrm{H}$ tone one syllable rightwards into a non-final syllable, a process which does not move $\mathrm{H}$ from a subject prefix to a verb root or object prefix. A second H-dissimilation process, Reverse Meeussen's Rule, deletes $\mathrm{H}$ before $\mathrm{H}$ in an object prefix or the copula. It was also shown that a final $\mathrm{H}$ tone in a verb will shift into a following complement, and that a final $\mathrm{H}$ may arise either with lexically $\mathrm{H}$ toned monosyllabic verb stems, or with any stem bearing the reflex of an earlier tense-aspect conditional melodic $\mathrm{H}$.

\section{Comparative Tonology of Mbololo.}

Synchronic analysis of tone alternations in the Dembwa dialect of Taita also motivates an underlying three-way distinction in noun tone between toneless stems (which are tonally inert), those with final $\mathrm{H}$ (which shifts into the following modifier or deletes prepausally), and penult $\mathrm{H}$ which spreads or shifts to the final syllable - see Odden (2001) for details. Although the surface behavioral classes are roughly similar, the lexical correspondence between the classes is not one-to-one in the two dialects. The three-way distinction in Dembwa nouns is reduced in Mbololo to a two-way distinction with lexically irregular failure of tone shift. Simple examples of the Dembwa tone classes are given in (60). The appearance of $\mathrm{H}$ two syllables after the noun is a reflection of Dembwa's shifting and delinking processes. The underlying forms of the nouns are / $\beta \mathrm{andu} /, / \beta a k a$ / and /yóndi/.

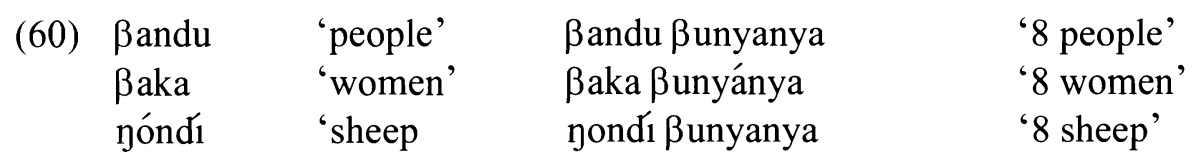


Comparison of Mbololo and Dembwa nouns shows that the toneless nouns of Dembwa correspond to toneless nouns in Mbololo. The preceding sections show that these nouns are toneless in Mbololo, and the Dembwa form before Bunyanya " 8 " reveals the underlying tone - $\mathrm{H}$ nouns condition a $\mathrm{H}$ on the following adjective (Dembwa does not automatically insert $\mathrm{H}$ after toneless nouns).

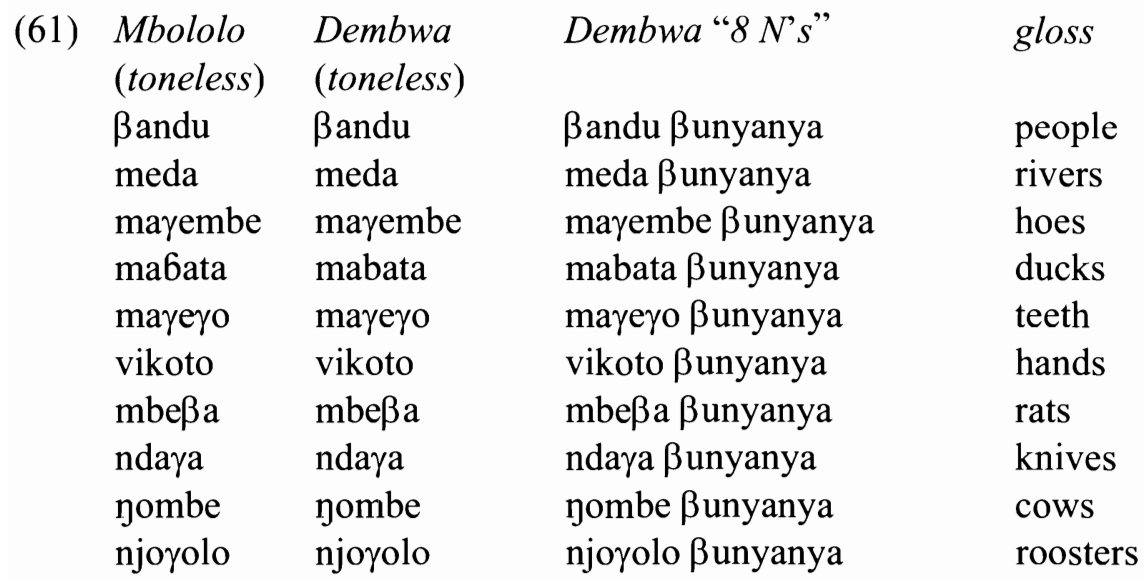

Nouns in the $\mathrm{H}$ class of Dembwa (those with an underlying final $\mathrm{H}$, which causes assignment of a $\mathrm{H}$ on the following modifier) also correspond to nouns in the toneless class of Mbololo.

\begin{tabular}{|c|c|c|c|}
\hline $\begin{array}{ll}\text { (62) } & \text { Mbololo } \\
& \text { (toneless) }\end{array}$ & $\begin{array}{l}\text { Dembwa } \\
(H)\end{array}$ & Dembwa "8 N's" & gloss \\
\hline 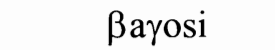 & $\beta$ agosi & $\beta$ agosi $\beta$ unyánya & old men \\
\hline ßaka & $\beta$ aka & $\beta$ aka $\beta$ unyánya & women \\
\hline midi & midi & midi $\beta$ unyánya & trees \\
\hline vongo & vongo & vongo $\beta$ unyánya & heads \\
\hline masoka & masoka & masoka $\beta$ unyánya & axes \\
\hline nyumba & nyumba & nyumba $\beta$ unyánya & houses \\
\hline $\mathrm{mbu} \beta \mathrm{a}$ & $\mathrm{mbu} \beta \mathrm{a}$ & mbußa $\beta$ unyánya & gardens \\
\hline ndana & ndana & ndana ßunyánya & bows \\
\hline nyungu & nyungu & nyungu $\beta$ unyánya & pots \\
\hline
\end{tabular}

The class of $\mathrm{H}$ nouns of Mbololo, with underlying final $\mathrm{H}$, corresponds to the penult-H class of nouns of Dembwa in the following examples. 


\begin{tabular}{|c|c|c|c|}
\hline $\begin{array}{l}\text { (63) } \begin{array}{l}\text { Mbololo } \\
(H)\end{array}\end{array}$ & $\begin{array}{l}\text { Dembwa } \\
\text { (penult-H) }\end{array}$ & Dembwa "8 N's" & gloss \\
\hline vala & válá & valá ßunyanya & hands \\
\hline matuku & matúkú & matukú $\beta$ unyanya & days \\
\hline koši & kóší & koší ßunyanya & dogs \\
\hline čoka & čóká & choká $\beta$ unyanya & snakes \\
\hline mburi & mbúrí & mburí $\beta$ unyanya & goats \\
\hline tindi & tíndí & tindí $\beta$ unyanya & tomatoes \\
\hline nguku & ngúkú & ngukú ßunyanya & chickens \\
\hline mizata & mizátá & mizatá ßunyanya & sticks \\
\hline
\end{tabular}

This suggests a standard correspondence and sound change: final $\mathrm{H}$ deletes in Mbololo, resulting in lexical restructuring, and penult $\mathrm{H}$ subsequently shifts to the right, giving the synchronic / $\mathrm{CVCV} /$ structure of $\mathrm{H}$ nouns in Mbololo.

However, not all Dembwa penult-H nouns correspond to (final)-H nouns in Mbololo. In the following examples, the penult-H nouns of Mbololo also correspond to Dembwa penult-H nouns. Recall that there are relatively few penult-H nouns in Mbololo. ${ }^{12}$

$\begin{array}{llll}\text { (64) } \begin{array}{lll}\text { Mbololo } \\ (H)\end{array} & \begin{array}{l}\text { Dembwa } \\ \text { (penult- } H)\end{array} & \text { Dembwa "8 N's" } & \text { gloss } \\ \text { misénge } & \text { miséngé } & \text { misengé } \beta \text { unyanya } & \text { sticks } \\ \text { misídu } & \text { misídú } & \text { misidú } \beta \text { unyanya } & \text { forests } \\ \text { mafúmu } & \text { mafúmú } & \text { mafumú } \beta \text { unyanya } & \text { spears } \\ \text { jóndi } & \text { jóndí } & \text { nondí } \beta \text { unyanya } & \text { sheep } \\ \text { ngánga } & \text { ngángá } & \text { ngangá } \beta \text { unyanya } & \text { guinea fowl }\end{array}$

I assume that the historical process shifting penult $\mathrm{H}$ to the final syllable, which affected most nouns with an original penult $\mathrm{H}$, applied incompletely in Mbololo.

Toneless nouns of Dembwa correspond to LL nouns of proto-Bantu or LL patterns in geographically close and tonally conservative (Gonja) Kipare, see for

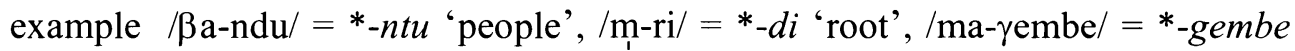

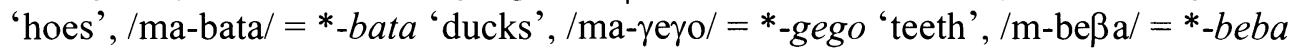
'rats', /nombe/ = * yombe 'cow'; /moda/ = Kipare $m$ w-eta 'river'. The nouns

\footnotetext{
${ }^{12}$ Philippson 1991 also notes such a pattern in the Josa dialect and observes that the number of such nouns is very low: apart from msénge 'stick', none of those nouns appears in my data.
} 
which are underlyingly $\mathrm{H}$-final in Dembwa reflect a historically earlier LH pattern, as exemplified by $/ \mathrm{mi}^{-} \mathbf{d}_{\mathbf{1}} /=*_{-}-t^{\prime}$ 'tree', /nyumbá/ $=*_{j u m b a ́}$ 'house', /masoká/ = *coká 'axe', /nyungú/ = *jungú 'pot'; / men', / $\beta \mathrm{a}-\mathrm{ka} /$ = Kipare $v a-\check{c} e ́$ 'women. Nouns which in Dembwa have underlying $/ \mathrm{HL} /$ (citation $[\mathrm{HH}]$ ) nouns correspond to earlier *HL (mbúrí = *búdi 'goat', čóká = *jóka 'snake', m-sídú = *títu 'forest', ngángá = *-kánga 'guinea fowl' i-fúmú =*-túmo 'spear', m-kónú = *kóno 'arm').

The historical development of original ${ }^{*} \mathrm{HH}$ is more difficult to trace in the dialects which I have worked on. Philippson (1991) notes the correspondence $\mathrm{HH}$ $\rightarrow$ LL in singo 'neck', msaßi 'sorcerer' which trigger $\mathrm{H}$ on the following word - as H-final nouns of Dembwa do — and (p.c.) finds that correspondence in a number of other words. My notes include a few such nouns, including $/ \mathrm{m}-\mathrm{sa} \beta^{\prime}$ / 'sorcerer', /m-lambá/ 'baobab', /i-indi/ 'bone' and /mbangá/, the latter three of which are reconstructed by Guthrie as having *HL tone (Gerard Philippson p.c. argues that Guthrie's tonal reconstructions are mistaken). I also have the correspondence ${ }^{*} \mathrm{HH}=/ \mathrm{HL} / \rightarrow[\mathrm{HH}] \quad\left(n g u ́ k u ́=* k\right.$ ${ }^{*} k u ́$ 'chicken', ma-bémbá = *-pémbé 'corn'; m-zátá = Kipare n-zátá 'stick', máčí 'water' = Kipare mází), only the first of which unquestionably reflects proto-Bantu. Given the small number of stems with uncontroversial proto-Bantu $\mathrm{HH}$ appearing in my Taita data, it is impossible to draw firm conclusions, but based on Philippson's data for the Josa dialect I assume that $[\mathrm{HH}]$ is not a regular correspondence for Dembwa and Mbololo.

In the synchronic tonal grammar, the Dembwa and Mbololo dialects have in common certain patterns, including nearly universal ones in Bantu such as the two-way root-initial tone contrast in verbs and some system of melodic tone marking tense-aspect distinctions, as well as more language-specific patterns such as emergence of downstep under $\mathrm{H}$-concatenation and the loss of underlying word-final $\mathrm{H}$. The tendency for rightward shift is found in both dialects, but the specifics of shift and spread differ. Dembwa has a more extensive system of tone spreading and shifting, where $H$ tone can shift two syllables to the right - thus Dembwa /ku-dáfuna nyama/ $\rightarrow$ [ku-dafuná nyama] 'to chew meat' (vs. Mbololo [kudafúna nyama]). This double-shifting pattern is only found in connection with phrasal combinations or across the macro-stem boundary, so contrast / ku-dáfunia/ $\rightarrow$ [kudafúnia] in both Mbololo and Demba. The main differences are summarized below. 


\section{(65) Mbololo \\ No [HH] \\ Only one H shift \\ Direct shifting a possible analysis}

No prepausal H's at all

Insertion of $\mathrm{H}$ in NP after toneless $\mathrm{N}$

\section{Dembwa}

$[\mathrm{HH}]$ possible if one of the two syllables is the penult

Phrasally-conditioned secondary shift, including across macro-stem boundary

Clear decomposition of shift into (broader) spread and (narrower) delinking

Prepausal $\mathrm{H}$ arises via spreading (always [HH\#]

No H insertion

Mbololo might seem to be a bit more tonally conservative, in not having the double-shifting of the Dembwa dialect, but overall, Mbololo has a more innovative tonal phonology. Both dialects have final lowering where a single prepausal $\mathrm{H}$ is deleted, so that earlier *nyumbá 'house' becomes [nyumba] in Mbololo and Dembwa. The difference between the dialects lies in the fact that final $\mathrm{H}$ is synchronically preserved in the underlying form in Dembwa (as seen from the fact that $\mathrm{H}$ shifts from the noun to a modifier - nyumba Bunyánya ' 8 houses'), but in Mbololo, original final-H nouns have all been relexicalized as toneless, thus neutralizing the patterns of earlier *ngombe and *nyumbá — see Mbololo nombe éegwa 'the cow fell', nyumba éegwa 'the house fell'.

The Mbololo dialect has generalized left-branch delinking, so that where original ${ }^{*} \mathrm{HL} \rightarrow \mathrm{HH}$ in Dembwa, such an output undergoes regressive delinking to give underlying LH in Mbololo (compare Dembwa kudáfûna vs. Mbololo kudafúna). This delinking process feeds final-lowering. The synchronic rule of final lowering may be identical between the dialects, deleting any singly-linked final $\mathrm{H}$. It is likely, however, based on the correspondence in nouns where proto-Bantu ${ }^{*} \mathrm{HH}$ appears as LL, that an earlier form of the rule applied to all final $\mathrm{H}$ tones, regardless of whether the $\mathrm{H}$ was multiply-linked. Dembwa has no lowering in kóšl "dogs" because the final $\mathrm{H}$ is multiply-linked, but in Mbololo, which does not have surface ...HH... at all, kóšs may have first changed to koši due to unrestricted delinking, which then became [koši] due to general final lowering.

A seeming puzzle arises from the fact that a systematic set of historical $\mathrm{HL}$ words appear as HL in Mbololo rather than being restructured to $/ \mathrm{LH} /$ : see infinitives (and other inflected forms) such as earlier *kubóna $\rightarrow$ [kußóna] 'to see' (Dembwa [kußóná]), contrasting with nouns such as *kóši $\rightarrow$ Mbololo /košíl $=$ 
[koši], in not becoming / ßoná/ = [ßona]. The different shifting patterns in nouns and verbs reflect their different grammatical statuses. The position of the underlying $\mathrm{H}$ tone in a verb stem is non-lexical - it is entirely predictable, always on the first vowel of the stem, and the final vowel $-a$ is a distinct inflectional morpheme with no underlying tone. The evidence of paradigmatic alternations thus makes impossible lexical reanalysis of the $\mathrm{H}$ shift in verbs, and /ku- $\beta$ ón-a/ could not be reanalyzed as /ku- $\beta$ on-á/. In contrast, because roots such as * kóši are morphologically simple and the position of $\mathrm{H}$ in a noun was not rule-governed, there was no structural impediment to relexicalizing a phonetic output [koši] as underlying /košl/, which is the synchronic underlying form in the Mbololo dialect.

The exact realization of $\mathrm{H}$-shifting in Taita dialects appears rather varied. In the following comparisons, the Josa data are from Philippson 1991, and Rong'e data are from my own notes.

\begin{tabular}{|c|c|c|c|}
\hline Dembwa & CVCV & ku-ßóná & 'to see' \\
\hline & CVCVCV & ku-dáfûna & 'to chew' \\
\hline Mbololo & CVCV & ku-ßóna & 'to see' \\
\hline & CVCVCV & ku-dafúna & 'to chew' \\
\hline Josa & CVCV & ku-lodá & 'to dream \\
\hline & CVCVCV & ku-dafúna & 'to chew' \\
\hline Rong'e & $\begin{array}{l}\text { CVCV } \\
\text { CVCVCV }\end{array}$ & ku-ßóná & 'to see', \\
\hline
\end{tabular}

Three parameters of variations can be inferred from analysis of the dialects. The first is rightward spread, to be further distinguished as primary spread plus secondary spread involving proximity to word boundaries. Second, the spreading process may show resistance of final syllables to receiving $H$. Third, the languages may show left-branch delinking (unrestricted or restricted from applying to certain penultimate or antepenultimate syllables). Dembwa has unrestricted primary spreading which means that $\mathrm{H}$ always spreads one syllable to the right; it also has restricted secondary spreading which means that $\mathrm{H}$ will spread again across or into word-final position as long as the target is not phrase-final; and it has restricted left branch delinking, meaning roughly that doubly-linked $\mathrm{H}$ is preserved when one branch of the $\mathrm{H}$ is on a long penult (the conditions are more complex: see Odden 2001 for further discussion). Mbololo, on the other hand, has restricted primary spreading (no spreading to the final syllable), no synchronic secondary spreading but evidence of earlier unrestricted secondary spreading in nouns, and unrestricted left branch delinking (HH is unattested). The data from Josa suggest 
unrestricted primary spreading and unrestricted left branch delinking, and the data from Rong'e suggest unrestricted primary and secondary spreading, and restricted left branch delinking.

(67)

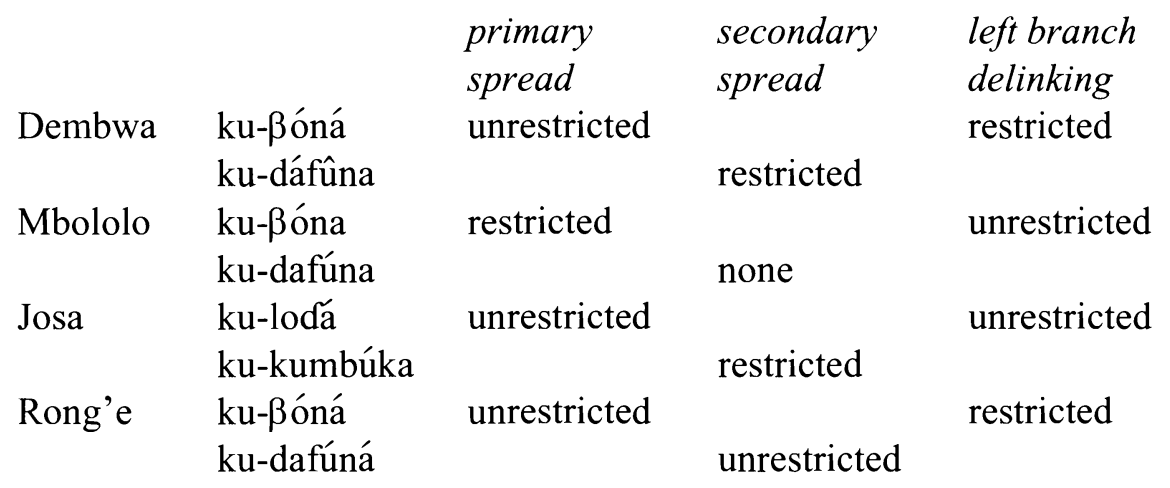

Further descriptive and dialect research will be required in order to determine what other tonal patterns are found in Taita, and whether "proto-Taita" fully retained the 4-way system of nominal contrasts from proto-Bantu. 


\section{REFERENCES}

Bickmore, Lee. 2001. "Downstep and fusion in Namwanga". Phonology 17: 297333.

Clements, G.N. 1985. "The geometry of phonological features". Phonology Yearbook 2: 225-252.

Downing, Laura. 1996. The Tonal Phonology of Jita. Lincom Europa: Munich.

Hyman, Larry M. 1978. "Tone and/or accent". Elements of Tone, Stress and Intonation, ed. by Donna Jo Napoli. Washington: Georgetown University Press. Pp. 1-20.

Kanerva, Jonni. 1990. Focus and Phrasing in Chichewa Phonology. Stanford: Stanford University, Doctoral dissertation.

Kisseberth, Charles \& David Odden. 2003. “Tone”. The Bantu Languages, ed. by Derek Nurse \& Gerard Philippson. London \& NY: Routledge. Pp. 59-70.

Kisseberth, Charles. 1984. "Digo tonology". Autosegmental Studies in Bantu Tonology, ed. by G. N. Clements \& John Goldsmith. Dordrecht: Foris. Pp. 105182.

Leung, Elizabeth. 1991. The Tonal Phonology of Llogoori: A Study of Llogoori Verbs. Working Papers of the Cornell Phonetics Lab, No. 6.

Odden, David. 2000. “Opacity and ordering: H-deletion in Kikerewe”. Linguistic Review 17: 323-335.

Odden, David. 1982. "Tonal phenomena in Kishambaa". Studies in African Linguistics 13: 177-208.

Odden, David. 1985. "Three dialects of Kipare". Current Approaches to African Linguistics, Vol. 3., ed. by Gerritt Dimmendaal. Dordrecht: Foris. Pp. 257280. 
Odden, David. 1996. The phonology and morphology of Kimatuumbi. Oxford: Clarendon Press.

Odden, David. 2000. "The phrasal tonology of Zinza". Journal of African Languages and Linguistics 21: 45-75.

Odden, David. 2001. "Tone shift and spread in Taita I". Studies in African Linguistics 30: 75-110.

Philippson, Gerard. 1991. Tons et accent dans les langues bantu d'afrique orientale: étude comparative, typologique et diachronique. Paris: Universite Paris $\mathrm{V}$, Doctorat d'etat.

Philippson, Gerard \& Marie-Laure Montlahuc. 2003. "Kilimanjaro Bantu (E60 and E74)". The Bantu Languages, ed. by Derek Nurse \& Gerard Philippson. London \& NY: Routledge. Pp. 475-500.

Poletto, Robert. 1998. Topics In Runyankore Phonology. Columbus: OSU, Doctoral dissertation.

Department of Linguistics

222 Oxley Hall

Ohio State University

Columbus, $\mathrm{OH} 43210$

odden@ling.osu.edu [received June 5, 2006

accepted Sept. 12, 2006] 